\title{
THEORY AND PRACTICE OF LITERARY HISTORIOGRAPHY IN BRAZIL, 1950S: A LOOK INTO THE CORPORATE LOGIC OF A MODERNIST INSTITUTION
}

\author{
Saulo Gouveia \\ Michigan State University
}

\section{Introduction}

Educational institutions and the state cultural apparatus play a decisive role in canon formation. As an academic subfield usually linked to institutions of higher education and sometimes to government agencies, literary historiography attempts to give the national canon a fixed form, a chronological and thematic structure that aims to regulate the study of literature in the educational field. The literary canon itself, this imaginary totality of the most relevant authors and works, suffers continuous modifications as it is always subject to constant appropriations, reinterpretations, and reconfigurations. The numerous volumes of literary history are conceived as imperfect, limited and partial materializations of the incommensurable totality of the canon. Based on Pierre Bourdieu's concept of cultural capital, John Guillory argues that, however complex, the process of canon formation is ultimately defined by the uneven distribution of this cultural capital in a given social group. ${ }^{1}$ The revisions that occur from time to time reflect the ideals of those who occupy the highest positions in the educational state apparatus, who impose the legitimate modes of reading and consuming literature. Factors such as the identity-politics agenda, the efforts to foster a more diverse and representative liberal curriculum are important elements but they still play a secondary role in the process of canon formation.

In the case of the studies in Brazilian literature, in spite of the fact that there are several well-established specialized areas of criticism concerned with issues of gender, race, ethnicity, and sexuality, that challenge the centralized view of

\footnotetext{
${ }^{1}$ For an extensive discussion of the problem of canon formation as well as Bourdieu's concept of cultural capital, see Guillory, Cultural Capital 3-82.
} 
the canon, literary history continues to overrule and ignore these developments in the field of criticism. Literary histories continue to be structured around a centralized and broad definition of national identity. A prime example of this practice in recent years can be found in José Aderaldo Castello's História da Literatura Brasileira: Origens e Unidade, 1999. In this two-volume anthology, there are no sections that take into account issues of non-hegemonic ethnicities, religious practices, homosexuality or gender as structuring categories. As the subtitle "Origins and Unity" suggests, this study overlooks all markers of difference, presenting a homogenizing narrative of Brazilianess. The publication of Castello's work could be seen as celebration of fifty years of the same rhetoric that had been established by the body of historiography that came out in the 1950s, when Castello himself emerged among a group literary critics and historians.

My essay will examine issues related to canon formation primarily in literary historiography that was established in Brazil during the 1950s. The specific questions I will address are: What are the theoretical and methodological approaches that inform literary historiography in Brazil? What is the position of literary historiography in the field of cultural production? Who are the authors and ideologues in this field? What are the institutions that legitimize this field? What is the relationship between theory and the ideology expressed in the discourse of literary histories? I propose a brief overview of the theoretical and methodological guidelines of two decisive moments in the field of literary historiography in Brazil during the twentieth century. It is well known that the first and most decisive moment in this academic area takes place around the turn of the century, during the first Republican regime, with the works of Sílvio Romero and José Veríssimo. I argue that the second significant moment happens in the 1950 s, when a wide array of literary history studies appear. My essay focuses mostly on the literary histories of the 1950s, and it is divided into three sections: The first attempts to define and situate the field of literary historiography within the field of cultural production. The second section contains 
an inventory of the 1950s publications with brief analysis of their format and contents as well as biographical information about the authors of these publications. The third section analyzes the discourse and the ideology of literary historiography with regard to the Modernist moment, which offer a valuable clue as to the ideological orientation of this body of scholarship at the time.

\section{Literary Historiography's Method and Position in the Cultural Field}

Literary historiography functions as a bridge between literary production and the educational system. It is also an area that has been historically associated with nationalist ideals. The volumes of literary history produced over a period of time form a body of work that provides a master narrative of national identity. In Brazil, Silvio Romero's História da literatura brasileira ${ }_{2} 1888,{ }^{2}$ for instance, is often cited as one of the foundational texts of the Republican era nationalism. Romero tries to establish a Naturalist type of criticism as a reaction against the Romantic mode of thought (Ventura 4041). He studies the literature produced in Brazil in order to observe and theorize about general traits of Brazilian society. For Romero, literature is a product of the socio-historical, racial, and environmental conditions of a given time and place. He applies concepts from Comte, Darwin, Spencer, and Taine to conclude that the particularities of the environment and race in Brazil obstruct progress towards a civilized society. While the author privileges racial miscegenation as a distinctive element of Brazilian society, he also evaluates this as a negative trait. One of the unique features of Romero's project is that he conceives of literary historiography not as an autonomous area but as a subsidiary of the social sciences. The author attempted to find answers to broad social issues through the study of literature, not simply to historicize formal features of national literary production.

\footnotetext{
2 For an excellent analysis of Silvio Romero's work as one of the originators of the social sciences in Brazil see Ortiz, Cultura brasileira 1335. See also Ventura, "História e Crítica em Sílvio Romero," Malard et al. História da literatura. 34-54.
} 
Another landmark work in the area of literary historiography was José Veríssimo's História da literatura brasileira, 1916. Veríssimo introduces an impressionistic method of criticism borrowed from late nineteenth century art pour l'art theoreticians Gustave Lanson, Anatole France, and Jules Lemaitre (Ventura 49-50). His approach privileges the literary work as the primary object of analysis and his evaluative criterion relies heavily on the classical aesthetic concept of belles-lettres. According to Veríssimo, everything that is not literary should be excluded from the history of Brazilian literature; thus, literature and art possess a historicity of their own. Even though his aestheticism implies reproduction of classical European standards of formal excellence, Veríssimo considers the literature produced in Brazil to be completely emancipated from that of Portugal. He makes, then, a nationalist claim that attempts to overcome the charge of cultural dependence. Therefore, his discourse does in fact extrapolate the strict realm literary analysis and ventures into cultural politics.

Romero's and Veríssimo's versions of the history of Brazilian literature represent opposing, irreconcilable models of literary historiography. Veríssimo's formalist approach advocates the historicity of the aesthetic object, while Romero's sociological approach utilizes literary products as documents that reveal particular aspects of society as a whole. This theoretical and methodological dichotomy would continue to influence and divide the field of literary historiography for many decades. However, the fact that authors with such conflicting definitions of the literary phenomenon in many ways converge in affirming traces of originality and emancipation of the Brazilian literary expression proves that the purpose of literary historiography is ultimately to define original features of the literary canon that contain symbolic elements of national identity. This apparently tacit agreement within a heterogeneous group of scholars represents an aspect of what Pierre Bourdieu defines as habitus in the academic profession. The habitus is the result of a long process of apprenticeship that produces individual and collective practices. It is a "system of dispositions . . it is the principle 


\section{Literary Historiography in Brazil}

of continuity and regularity which objectivism sees in social practices without being able to account for it" (The Logic of Practice 54). The habitus, as a system of "structured, structuring dispositions," tends to overrule internal oppositions in favor of practical functions of the organism, although it does not preclude the possibility of calculated and unorthodox dispositions within a certain organism (52-3). In the case of literary historiography in the $1950 \mathrm{~s}$, only Antonio Candido seems to have opted for an unorthodox methodology and approach, as I will demonstrate below. All other traditional histories show little or no variation at all. That is, they present a unified view of the literary phenomenon, with a particularly homogeneous attitude toward the historical meaning of the Modernist movement. Issues related to material conditions of production and circulation of literary products, and other aspects related to the literary field are largely disregarded.

According to Bourdieu, the educational system is a sphere of legitimization and consecration of symbolic production. It is the institutional space of reproduction of power relations and imposition of hegemonic values, which constitute "symbolic violence." Intellectuals (auctores), according to Bourdieu's conceptual system, belong to the "field of cultural production," which occupies a dominated position within the "field of power." Intellectuals possess symbolic forms of capital, cultural capital, but lower economic capital than others in the "field of power." Similarly, literary historians and critics (lectores) occupy a dominated position within the field of power, but a relatively high position in the cultural field. They are assigned the role of dissemination, iteration and, not infrequently, conceptualization of the literary sphere, in and for the educational system. They help establish the canon by taking part with the auctores and other agents in the struggle for the imposition of modes of consumption.

There is, however, another unspoken side of this ideology that guarantees its legitimacy and reproduction. Literary

\footnotetext{
${ }^{3}$ Although intellectuals are usually in the dominated position, they are often in close proximity to the "field of power" because of their cultural capital. In some cases, they even occupy positions in the "field of power." See Bourdieu, "The Field" 38-39.
} 


\section{Saulo Gouveia}

historians rarely question the process of selection of texts and authors that in their view represent national literature. The presumed all-inclusive inventory of national authors of literary historiography tends to impart the notion of neutrality and disinterest on the part of the historian. What could be termed the "principle of disinterestedness" governs literary historians' analysis of literary works. "Disinterestedness," or the claim of neutrality and impartiality, allows critics and historians to take political and ideological positions based on assumptions about the literary text's legitimacy without textually justifying them. As Johnson summarizes Bourdieu's concept of symbolic violence: "The establishment of a canon in the guise of a universally valued cultural inheritance or patrimony constitutes an act of 'symbolic violence,' as Bourdieu defines the term, in that it gains legitimacy by misrecognizing the underlying power relations which serve, in part, to guarantee the continued reproduction of the legitimacy of those who produce or defend the canon" (Johnson, "Editor's Introduction" 20). While imposing a given set of values, critics and historians of literature also make an implicit statement about their own legitimacy and authority in the cultural field. Even though the literary historians' authority imposes itself throughout the entire cultural field, it is primarily circumscribed within the educational sector, which is both the institutionalized space of production of literary historiography (high-ranking positions in universities) and its intended audience (high school, college level students).

Literary historians, critics, publishers, teachers and sponsors combine efforts to produce symbolic value or the "belief in the value of the work" (Bourdieu, "The Field" 37). The symbolic value added through the work of criticism and historiography ensures longevity to the literary and artistic work. Thus, literary historians certainly fulfill the ambition to act as auctores by selecting and judging the "aesthetic value" of a given text and assigning meaning to the literary production under consideration. Historians are, in fact, imposing modes of consumption of literary texts and guaranteeing the 
reproduction of the hegemonic view of the canon in the educational system.

As a highly institutionalized academic area, the field of literary historiography assures a high degree of consecration for both the literary historian and the authors and works they choose to analyze. As a vehicle of nationalistic discourse designed for the educational setting, literary historiography does not usually foster transformations in the cultural field. On the contrary, it tends to consolidate past struggles for legitimization in the literary field. In other words, the inclusion of a given work in literary historiography represents one of the last phases in the process of institutionalization of literary production. The field of literary historiography works in favor of notions of permanence, perpetuation, consecration, canonization, centralization and standardization of literary patrimony. The task of the literary historians of the 1950s was, however, more complex than simply updating the list of authors and works to the established Brazilian literary canon. They somehow carried out the contradictory task of maintaining the traditional canon while trying to give it a seemingly new outlook. In order to understand the functioning of a academic field such as historiography, it is not enough to examine the theoretical and methodological approaches, or even the reigning ideology of a field in a particular historical context. As Bourdieu points out, in order to study a cultural field in a given period or society, there needs to be a radical contextualization: "The task is that of constructing the space of positions and the space of position-takings [prises de position] in which they are expressed" (Bourdieu, "The Field" 30). Thus, in the following section I will attempt to construct a list of the main authors of historiography in the $1950 \mathrm{~s}$, their theoretical and methodological approaches, as well as the position they occupied in educational institutions and, in some cases, the position they occupied within the state cultural apparatus.

\section{Brazilian Literary Historians of the 1950s}

The field of literary historiography in Brazil underwent its most significant change in the 1950 s, when a large number of 


\section{Saulo Gouveia}

studies were published and a new generation of literary historians and critics appeared. With the exception of Antonio Candido's Formação da literatura brasileira, 1959, the new works of literary history did not necessarily establish new benchmarks or bring innovations to the field. The decade was the most prolific period for this academic area, producing a variety of types/formats and approaches. According to Letícia Malard, between the publication of José Veríssimo's História da literatura brasileira in 1916 and the 1950s boom, there were studies by Ronald de Carvalho, 1919, and Artur Mota, 1930. In her assessment, the only comprehensive volume with an entirely new approach to be published between 1916 and the 1950s was the first edition of Nelson Werneck Sodré's História da literatura brasileira: Seus fundamentos econômicos, first published in $1938 .^{4}$

The great majority of these 1950s studies tend to follow a formalistic approach, which vindicates the autonomy of the literary field, and by extension, the autonomy of the field of literary historiography. In this regard, the new studies were closer to José Veríssimo's than to Silvio Romero's view of the literary phenomenon. These formal premises inform, for example, the work of Afrânio Coutinho:

\footnotetext{
Tentando-se adaptar o método genológico ao estilístico, . . . o fenômeno literário é encarado-insista-se-como fenômeno autônomo, não subordinado, mas equivalente às outras formas de vida [sic] com as quais se relaciona. Em suma, o princípio da ordem da obra é estético, não histórico. (Introdução 74)
}

The literary historians of the 1950s strived to give a new identity to the Brazilian literary canon. The organizing principles that inform these studies were based on orthodox values of high culture, but they did not entirely exclude the vernacular, folklore, and other features of Brazilian popular

\footnotetext{
4 The 1938 edition was published by José Olympio in the Coleção Documentos Brasileiros series. A revised version was published 1960 by José Olympio and then in 1964 by Civilização Brasileira. Sodré's analysis of the modernist movement in his 1938 version of his project was quite sketchy with no reference to specific titles. For a detailed study of Sodré's work, see Malard "Nelson Werneck Sodré: A ruptura e o reflexo." Malard et. al. História da literatura. 55-74.
} 


\section{Literary Historiography in Brazil}

culture that were valued by the Modernists as original. There is almost a consensus among these authors in condemning the urbane and cosmopolitan prose that was in vogue at the turn of the century. As Jeffrey Needell observed, the "heirs of the Modernists, recent readers and critics usually accept the Modernist condemnation of the Brazilian fin de siècle as affected and superficial" (184). This replication of the early Modernist's scorn for the art nouveau prose of the turn of the century is a sign that literary historians construct their discourses as a continuum with the Modernist texts. In fact, such continuity is publicly admitted. Wilson Martins, one of the most enthusiastic historians of Modernist literary production, identifies the 1950s as the "Era of Criticism." This is the period when he debuted as a critic and contributed to Coutinho's multi-volume project. In his view, this corresponds to the "third phase" of Brazilian Modernism ("A crítica modernista" 493-535).

Table 1 presents an array of the publication types that first appeared in the period. Not all of them fit perfectly under the category of literary historiography. In the case of the collaborative multi-volume collections, the year of publication corresponds to the earliest volume in the collection; in general, individual volumes of these collections appeared in different years. Most of the titles listed were subsequently republished, sometimes as revised versions through a different publishing house.

The table demonstrates the expansion and diversification of the editorial market in Brazil, even though it is still concentrated in Rio de Janeiro and São Paulo. This body of historiography volumes represents an editorial boom in this particular area. Some of the authors listed here were also in charge of the publishing companies that released their work. For example, Mário da Silva Brito was the director of Saraiva publishing house, and Alceu Amoroso Lima owned Agir publishing company. Some of these publications became classics and were reprinted several times (e.g. Antonio Candido's Formação and Afrânio Coutinho's Introdução). There 
Saulo Gouveia

Table 1: Authors, Titles, Publishers and Year of Publication

\begin{tabular}{|l|l|l|l|l|}
\hline \multicolumn{1}{|c|}{ Author } & Title & Publisher & Year & Vols \\
\hline $\begin{array}{l}\text { Amora, } \\
\text { Antônio } \\
\text { Soares }\end{array}$ & $\underline{\text { História da Literatura Brasileira }}$ & Saraiva, SP & 1955 & 1 \\
\hline $\begin{array}{l}\text { Brito, Mário da } \\
\text { Silva }\end{array}$ & $\frac{\text { História do Modernismo }}{\text { Brasileiro: Vol I Antecedentes }}$ & Saraiva, SP & 1958 & 1 \\
\hline $\begin{array}{l}\text { Candido, } \\
\text { Antonio }\end{array}$ & $\frac{\text { Formação da Literatura }}{\text { Brasileira: Momentos Decisivos }}$ & Martins, SP & 1959 & 2 \\
\hline $\begin{array}{l}\text { Coutinho, } \\
\text { Afrânio }\end{array}$ & $\underline{\text { Introdução à Literatura no Brasil }}$ & $\begin{array}{l}\text { São José, } \\
\text { RJ }\end{array}$ & 1959 & 1 \\
\hline $\begin{array}{l}\text { Coutinho, } \\
\text { Afrânio, ed. }\end{array}$ & $\underline{\text { A Literatura no Brasil Vol IV }}$ & $\begin{array}{l}\text { Sul } \\
\text { Americana, } \\
\text { RJ }\end{array}$ & 1959 & 6 \\
\hline $\begin{array}{l}\text { Lima, Alceu } \\
\text { Amoroso }\end{array}$ & $\underline{\text { Quadro Sintético da Literatura }}$ & Agir, RJ & 1956 & 1 \\
\hline $\begin{array}{l}\text { Lins, Álvaro, } \\
\text { ed. }\end{array}$ & $\underline{\text { História da Literatura Brasileira }}$ & $\begin{array}{l}\text { José } \\
\text { Olympio, } \\
\text { RJ }\end{array}$ & 1950 & 12 \\
\hline $\begin{array}{l}\text { Milliet, Sérgio } \\
\text { Werneck }\end{array}$ & $\frac{\text { Panorama da Moderna Poesia }}{\text { Brasileira }}$ & $\begin{array}{l}\text { MES, RJ } \\
\text { Seus fundamentos econômicos }\end{array}$ & $\begin{array}{l}1952 \\
\text { Olympio, } \\
\text { RJ }\end{array}$ & 1 \\
\hline
\end{tabular}

are significant dissimilarities among these publications. Most of them fall into the category of traditional literary histories, organized according to the classic division of stylistic periods. Some are brief literary manuals that target lower level students (e.g. Lima's Quadro sintético), and others are large and comprehensive studies that target the academic audience (e.g. Candido's Formação). Most of them cover the largest possible historical period, from the 1500s up until the middle of the twentieth century. These studies attempt to cover this wide range of literary production not in a strict chronological order but according to literary historiography's categories: Baroque; Neo-Classicism (Arcadismo); Romanticism; Realism; Naturalism; Symbolism; Parnassianism; and Modernism. There are only slight variations concerning the 
time periods and stylistic/thematic organization amongst them.

Álvaro Lins and Afrânio Coutinho are editors of the largest literary historiography projects. These are collaborative projects that launched an entire generation of critics and historians of literature. The unfinished project directed by Álvaro Lins was supposed to have contributions from Lúcia Miguel Pereira plus eleven other authors. ${ }^{5}$ Coutinho's A literatura no Brasil includes sections written by Mário da Silva Brito, Péricles Eugênio de Silva Ramos, Dirce Cortes Riedel, J. Alexandre Barbosa, José Aderaldo Castello, Luís Costa Lima, Sônia Brayner, Antônio Olinto, Adonias Filho, Walmir Ayala, Franklin de Oliveira, Ivo Barbieri, Waltensir Dutra, Xavier Placer,Wilson Martins and others. Coutinho is considered the leader of this entire generation of literary critics and historians who were part of the Crítica Nova movement. ${ }^{6}$

The only exceptions to these all-encompassing traditional structures and themes are: Antonio Candido's Formação da literatura brasileira; Sérgio Milliet's Panorama da moderna poesia brasileira; and Mário da Silva Brito's História do modernismo brasileiro. Candido's is the most complex project of these three. It maps literary production in Brazil from the eighteenth century, known as Arcadismo in literary historiography, until the mid-nineteenth century, with the first manifestations of Romanticism. The author argues that these were the "formative" years of what was to become modern Brazilian literature. Thus, modern and contemporary literary production are not included in the study, since, in his view, Brazilian literature had been fully developed since the midnineteenth century. Candido does not make reference to the Modernist movement in this particular study, but in subsequent works the critic does seem to endorse the general hegemonic view of the significance of Modernism. For

\footnotetext{
${ }^{5}$ Of the twelve volumes, only Lúcia Miguel Pereira's Prosa de ficção ended up being published.

${ }^{6}$ In reference to Afrânio Coutinho as the leader of this generation and for a list of their main work in literary criticism at the time, see Martins, "A crítica modernista" Coutinho ed. A literatura no Brasil 493-535.
} 
example, in the volume, Presença da literatura brasileira, which he co-authored with José Aderaldo Castello, this traditional view of Modernism is reinforced. However, of all the works listed above, Candido's Formação is the only to organize a vast array of literary production under a broad historical perspective. For the first time in the history of this genre, an author attempts to analyze issues of production, circulation and consumption of literary products. Candido's background as a sociologist and his interest in Silvio Romero's method certainly played a role in his concept of literature in Formação. Candido's thesis, Introdução ao método crítico de Silvio Romero, was defended in 1945. This study was later published as a book in 1963. Of the studies published in the 1950s, Formação is the only one to be somewhat inspired by Romero's sociological view of literature.

Mário da Silva Brito's project focuses on the events that preceded the Week of Modern Art, based on personal testimonies from some of the organizers, as well as other sources of information such as newspaper and magazine articles, personal letters and biographies. This is not an orthodox work of literary historiography. It is an interesting and valuable "behind the scenes" historical/journalistic account that excludes analysis of literary texts. Though it contains important background information and documentation about the official inception of the Modernist movement, Brito's account essentially reproduces the Modernist artists' view of the event, reinforcing a mythical view of the movement as a cultural revolution.

Finally, Sérgio Milliet's work is basically an anthology of Modernist poetry. Unlike Brito, Milliet focuses exclusively on textual analysis of the poems. Milliet's study is the one that least resembles conventional literary historiography. It does not concern itself with historicizing the movement as a whole but rather with analyzing the formal aspects of one of its genres. However, since the compilation of texts attempts to give the reader a panoramic view of Modernist poetry, it serves some of the purposes of historiography. Milliet's analysis privileges notions of freedom of poetic expression, 


\section{Literary Historiography in Brazil}

thematic originality, and other innovations he claims were brought about by the Modernists. Milliet himself was a Modernist poet and artist who participated in the 1922 Week of Modern Art. His book was published by the printing press of the Ministério da Educação e Saúde, an organ that was restructured during the Vargas administration and that was, under Gustavo Capanema's tenure, the main state cultural apparatus of that era (Williams 62-3). The fact that an official government press was invested in producing works of literary criticism devoted to the study of Modernist poetry is evidence that there was an effort from within the state to divulge and canonize Modernism.

Table 2 includes authors whose literary historiography projects appeared in the 1950s. It provides information about their educational background, their career, political affiliation (when available), and their links to specific institutions. The table shows a certain degree of specialization among the body or critics and historians, even though none of them earned degrees in literature (law degrees prevailed amongst this group). At least three of these authors dedicated themselves almost exclusively to the work of literary criticism and historiography. Few of these authors actually debuted in the 1950 s as critics. Still the 1950s marks the establishment of a semi-professional generation of literary critics who were not biographically connected to the Modernist movement. In this regard, the only exceptions in the list are Sérgio Milliet and Alceu Amoroso Lima, who belonged to the first Modernist generation.

Even though most of these authors did not hold degrees specifically in literature, they were able to establish a career in the field of criticism and historiography by virtue of their institutional connections. These institutional connections demonstrate clearly that some of literary historians of that time were not only associated with the educational side of the field of cultural production but also directly connected to the field of power. For example, Alceu Amoroso Lima, Álvaro Lins, and Sérgio Milliet all occupied at some point in their career a high-ranking position within federal, municipal and state administrations. 


\section{Saulo Gouveia}

Table 2: Educational Background, Political Affiliations and Careers of Authors of Literary Histories published in the 1950s

\begin{tabular}{|c|c|c|c|c|}
\hline Name & \begin{tabular}{l|l} 
Birth \\
Death \\
\end{tabular} & Education & Career & Production \\
\hline $\begin{array}{l}\text { Amora, } \\
\text { Antônio }\end{array}$ & $\begin{array}{l}1917- \\
1999\end{array}$ & & $\begin{array}{l}\text { Literature prof., Acad.Paulista } \\
\text { de Letras. }\end{array}$ & $\begin{array}{l}\text { Literary criticism/ } \\
\text { historiography }\end{array}$ \\
\hline $\begin{array}{l}\text { Brito, } \\
\text { Mário da } \\
\text { Silva } \\
\end{array}$ & 1916- & Law (1943) & $\begin{array}{l}\text { Journalist, literary hist, poet. } \\
\text { Ed./dir. of Saraiva Pub.co. }\end{array}$ & $\begin{array}{l}\text { Journalism, } \\
\text { literary critic/hist, } \\
\text { poetry }\end{array}$ \\
\hline $\begin{array}{l}\text { Candido, } \\
\text { Antonio }\end{array}$ & 1918- & $\begin{array}{l}\text { Sociology } \\
\text { (1941) }\end{array}$ & $\begin{array}{l}\text { Prof. of sociology and literary } \\
\text { theory at USP. }\end{array}$ & $\begin{array}{l}\text { Lit. critic/hist, } \\
\text { sociology }\end{array}$ \\
\hline $\begin{array}{l}\text { Coutinho, } \\
\text { Afrânio }\end{array}$ & $\begin{array}{l}1911- \\
2000\end{array}$ & $\begin{array}{l}\text { Medical } \\
\text { School } \\
\text { (1931); Lit } \\
\text { Crit. (1947) }\end{array}$ & $\begin{array}{l}\text { Chair Lit. at Col. Pedro II } \\
\text { (1951-1965), Chair Lit. U. do } \\
\text { Brasil / UFRJ (1965-); vis. Prof. } \\
\text { at Amer univ. }\end{array}$ & $\begin{array}{l}\text { Lit. critic/ hist, } \\
\text { pedagogy, ref. } \\
\text { books }\end{array}$ \\
\hline $\begin{array}{l}\text { Lima, } \\
\text { Alceu } \\
\text { Amoroso }\end{array}$ & $\begin{array}{l}1893- \\
1983\end{array}$ & Law (1913) & $\begin{array}{l}\text { Lit. critic O Jornal; Dir. of } \\
\text { Centro Dom Vital; } \underline{\text { Acãão }} \\
\text { Católica }(1932-45) ; \text { Pres./Chair } \\
\text { of Soc. at U. do Dist. Fed. } \\
\text { (1937); Chair Lit. Fac. de Filos. } \\
\text { U. do Brasil (1938); Pres. } \\
\text { (PUC-RJ); }\end{array}$ & $\begin{array}{l}\text { Lit. critic/ hist, } \\
\text { sociology, } \\
\text { politics, } \\
\text { economics; } \\
\text { religion, philos. } \\
\text { pedagogy. }\end{array}$ \\
\hline $\begin{array}{l}\text { Lins, } \\
\text { Álvaro }\end{array}$ & $\begin{array}{l}1912- \\
1970\end{array}$ & Law (1932) & $\begin{array}{l}\text { State Secretary in } \\
\text { Pernambuco; Lit. critic Correio } \\
\text { da Manhã, RJ;. Prof. at Col. } \\
\text { Pedro II; taught in Lisbon } \\
\text { 1952-54. UNESCO ambass. }\end{array}$ & $\begin{array}{l}\text { Lit. critic/ hist, } \\
\text { biographies. }\end{array}$ \\
\hline $\begin{array}{l}\text { Milliet, } \\
\text { Sérgio }\end{array}$ & $\begin{array}{l}1898- \\
1966\end{array}$ & $\begin{array}{l}\text { Economics } \\
\text { and Social } \\
\text { Sciences } \\
(1916)\end{array}$ & $\begin{array}{l}\text { 1930s - Literary critic ( } \underline{ } \\
\text { Estado de São Paulo) } \\
\text { 1935-38; Dept. of Culture of } \\
\text { SP; Dir.of Mun. Library SP; } \\
\text { Pres. of Braz. Assoc. Art } \\
\text { Critics; Chair of Braz. Lit. U. of } \\
\text { Lausanne (Switzerland) }\end{array}$ & $\begin{array}{l}\text { Poetry, fiction, lit. } \\
\text { critic/ hist, art } \\
\text { critic/hist. }\end{array}$ \\
\hline $\begin{array}{l}\text { Sodré, } \\
\text { Nelson } \\
\text { Werneck }\end{array}$ & $\begin{array}{l}1911- \\
1999\end{array}$ & $\begin{array}{l}\text { Military } \\
\text { School } \\
(1933)\end{array}$ & $\begin{array}{l}\text { Military Service; } \\
\text { Prof. Esc. de Comando } \\
\text { Estado-Maior (1947-50); Prof. } \\
\text { ISEB (1955-64) }\end{array}$ & $\begin{array}{l}\text { Lit. critic/hist, } \\
\text { Hist, politics, } \\
\text { econ., hist. press. }\end{array}$ \\
\hline
\end{tabular}

Source: Coutinho and Sousa; Miceli; Fundação Getúlio Vargas. Centro de Pesquisa e Documentacão de História Contemporânea do Brasil. 2005. 23 April 2009.

<http://www.cpdoc.fgv.br/nav_gv/htm/biografias/Nelson_Werneck_Sodre.asp>

In sum, in the 1950s, literary criticism and historiography became, for the most part, specialized areas connected to educational institutions. What happened in the areas of literary criticism and historiography was the consolidation of a wider process of division of the intellectual labor fostered by the university. The expansion of the university system following Vargas's educational reforms in the 1930s and 
1940s demanded higher levels of specialization and autonomy of academic areas. These processes are all interrelated in another important way. As Johnson argues, the autonomization of the cultural field went hand in hand with the canonization of Modernism. In his assessment, these processes started in the early 1930s ("The Dynamics" 5). Therefore, there are direct links between the co-optation of Modernist intellectuals that happened during the Vargas administration and the immediate canonization of Modernism. I would argue that this canonization process is completed in the 1950s with this significant expansion in the field of literary historiography. The field was lead at the time by one of the intellectuals directly involved in the cultural and educational state apparatus of the Vargas administration who openly supported the Modernists since the beginning: Alceu Amoroso Lima. ${ }^{7}$

With the emergence of a professional body of literary critics and historians and the notion of an autonomous science of the literary phenomenon propagated by Russian Formalism, New Criticism, and Benedetto Croce's NeoHegelian Idealism, the field carried out a thorough reconfiguration of the national canon. As Alfredo Bosi argues, none of these tenets were rigorously incorporated or applied, as critics and historians seemed to propose an eclectic approach in which the "ideário nacional" continued to prevail (Literatura e resistência 27-8). This process involved not only the canonization of Modernism but a reinterpretation of the canon from the Modernist point of view. There is a Modernist imprint on the analysis of the entire body of Brazilian literature. A multi-faceted, yet unified, concept of Brazilianess is structured upon such pillars as: "Ethnic origins (the three races)," "Christianity (Catholicism)," "Folklore," "Regional cultures," "The Brazilian vernacular language," "Intellectual autonomy," "Aesthetic innovation and excel-

\footnotetext{
${ }^{7}$ For an extended analysis of the co-optation of Modernist intellectuals into the Vargas administration cultural and educational apparatus as well as the role of Alceu Amoroso Lima as the head of the Conselho Nacional de Educação, see Miceli, Intelectuais e classe dirigente. On the process of canonization that happened during and within the Vargas administration, see Johnson, "The Institutionalization of Brazilian Modernism," and "The Dynamics."
} 


\section{Saulo Gouveia}

lence." These categories, obviously, were not new and did not introduce an entirely new view of Brazilian culture, society and literature. However, with the development of a formalist "science" of literary criticism and historiography (New Criticism), these symbols were invoked and interpreted exclusively within the literary text. The circumstances involving production, circulation, reception, as well as biographical information about particular author were usually excluded from or disregarded in the 1950s corpus of literary historiography. With the exception of Antonio Candido's Formação, which converged with Romero's historical view, the 1950s literary historiography clashed with the Romerian version and aligned with José Veríssimo's historical view of the literary phenomenon. In the majority of the 1950s "histories" considered here, literary works of distinct time periods were given equal status within the history of ideas and individual creative genius. Many facets of various Modernist views of Brazilian culture were then applied retrospectively to a literary legacy of almost five hundred years. Therefore, the "third phase of Modernism," "the era of criticism" as defined by Martins, restated one of the most paradoxical attainments of the hegemonic Modernist view of Brazilian culture: the reinforcement of tradition under the guise of cultural modernization.

\section{The Modernist Legacy according to Literary Historiography}

From a methodological point of view, the official version of the Modernist movement has survived the rise and fall of various theoretical approaches to literature in academia. ${ }^{8}$ However, it is not by complete disregard for theoretical and methodological developments in the humanities that literary historians and critics have managed to keep the myth alive. On the contrary, scholars have adapted different methods to

\footnotetext{
${ }^{8}$ If we consider that the earliest critical/historical reviews of Modernism appear in the 1930s, we could say that, from 1930 to approximately 1979 when Miceli publishes Intelectuais e classe dirigente, criticism and historiography about Modernism have remained practically intact. The only variations concern textual interpretation, but the "meaning" of Modernism does not suffer any alteration.
} 


\section{Literary Historiography in Brazil}

accommodate the $a$ priori institutionalized historical view of Modernism, regardless of the fundamental demands of any given theoretical model. The somewhat diverse methodologies used partially reveal and partially hide the ideological position of individual historians. The discourse of these historians reveals their identification with the Modernist project, but the text elides information about the power relations that defined the cultural field at the time.

The discourse of the "Modernist historiography and criticism" highlights the formal experimentation put forth by the 1922 generation. According to this view, the first group of Modernist intellectuals set itself apart from the previous generation through the incorporation of avant-garde aesthetic features such as the use of parody, humor, collage, fragmentation, ellipsis - techniques often referred to as the "language of rupture." Formal experimentation is interpreted as a stable sign indicating a political and ideological breach with late nineteenth century symbolic production. Few of the literary histories analyzed here actually spell out the political issues involved in this "rupture with the past" other than an imperative need to renew and update Brazilian literature with the latest trends in Europe at the time. Those studies that do explore political and ideological issues tend to ascribe a double value to the Modernist contribution. On the one hand, vis-à-vis European culture, the appropriation of avant-garde techniques meant subversion of imported ideas (as implied in the concept of cannibalism). On the other hand, with regard to the local cultural production, the Modernist attitude meant a refusal of the "passive," "subservient" manner by which imported political and aesthetic forms had been previously incorporated by the Brazilian intelligentsia. As a prime example of this ideology, Afrânio Coutinho sets up the background and defines the movement's intended objectives:

O desejo de atualizar as letras nacionais - apesar de para tanto ser preciso importar idéias nascidas em centros culturais mais avançados - não implicava numa renegação do sentimento brasileiro. Afinal aquilo que Oswald [de Andrade] aspirava, a princípio sozinho, depois em companhia de outros jovens artistas e intelectuais, era tão somente a aplicação de novos processos artísticos às inspirações autóctones, e, concomitantemente, a 


\section{Saulo Gouveia}

colocação do país ... nas coordenadas estéticas já abertas pela nova era. (A literatura no Brasil 1)

Even though Coutinho advocates the supremacy of the aesthetic over the historical, his own arguments are founded on a historical and political imperative: the patriotic, nationalist sentiment that permeates the Modernist literary work. The Modernists' appropriation of national symbols, as well as their ideas about the intellectual's role in society, become political models for future generations. Yet, the actual political issues that those intellectuals were engaged in remain unspoken, implied in symbolic terms.

Alceu Amoroso Lima's introduction to the Modernist movement also describes a major battle between the intellectual establishment and the new generation of intellectuals. However, in spite of the heroic tone, the specifics of the political and cultural issues involved in such a conflict are not revealed:

O Modernismo, na sua fase inicial, iria ser, acima de tudo, um movimento contra. Dividiram-se os campos. Separaram-se as gerações. O moderno foi erigido em valor como tal. A preocupação em agredir a velha guarda literária e de procurar uma originalidade a todo transe, dominou o ambiente. (Quadro Sintético 68)

The language Lima employs to describe the inception of Modernism bears resemblance to that of military operations: this is a combative "counter movement," where "the field is divided," and "the modern is erected" as a flag. The young generation's aggression and their relentless search for originality signal their victory. That is, the victory that is being declared at the moment of enunciation of this historical account. It is clear that the history of Brazilian Modernism is the history of the winner. In a subtle but misleading statement Lima affirms that "modernity" is erected as a value by the Modernists, implicitly intellectuals, as if the previous generation did not accept modernity, or were not part of it. In fact, in one of Lima's earliest attempts to historicize Modernism in Brazil (Contribuição à história do modernismo: O premodernismo, 1939) the author creates the a-historical category of 


\section{Literary Historiography in Brazil}

"premodernismo" in reference to the Belle Époque - the turnof-the-century, literary production. The term is dubious since it can be interpreted both as that which preceded the Modernist movement, but also as a reference to a pre-modern period of time, which is a clear misconception. Therefore, Lima's first attempt to historicize Modernism represents, in fact, an effort to downgrade the literary production that preceded that of the Modernists of the 1920s. Despite being a-historical and anachronistic, the category "premodernismo" gained currency among critics and historians. It helped frame the Belle Époque authors as minor figures in the canon, unfulfilled precursors of Modernism. ${ }^{9}$

Fifteen years later Lima would write the manual that established rules for other historians to follow: Introdução à literatura brasileira, 1956. This is not an introduction to the literature itself but a set of methods and organizing principles for literary historiography. This particular version comes from the extreme right. As the leading Brazilian Catholic intellectual, Lima had been since the 1920s, the highest authority in the field of literary criticism in Brazil. One of the most powerful organic intellectuals in the Vargas regime, he had been in charge of legislating the educational field throughout most of the 1930s and 40s. When reading Lima's criticism, one has to bear in mind his high status in both the field of power and the field of cultural production and recognize that he was one of the main architects of the Modernist version of the history of Brazilian literature.

On the other side of the spectrum, the only historian of this generation to identify himself as a Marxist scholar in the 1950s is Nelson Werneck Sodré. In História da literatura brasileira: Seus fundamentos econômicos Sodré makes an effort to include historical and economic developments in his analysis. However, Sodré's arguments are remarkably similar to the others. In spite of including some reference to economic factors affecting literary production, he still follows the same formalistic/stylistic periodization as Coutinho (e.g.

\footnotetext{
${ }^{9}$ For example, Alfredo Bosi adopts the term in his História concisa and subsequently published an entire volume with the title O pré-modernismo. (São Paulo: Cultrix, 1973).
} 


\section{Saulo Gouveia}

Romanticism, Realism, Naturalism). Consequently, this is how Sodré contextualizes and evaluates the Modernist movement's accomplishments:

$\mathrm{O}$ ambiente que o Movimento Modernista encontrava era dos mais propícios ao irrompimento de alguma coisa nova. Dominava-o ainda o parnasianismo, com os poetas apegados ao soneto e os prosadores ao dicionário, inteiramente distanciados da vida e do mundo, trabalhando fora da realidade, na complicada elaboração de obras a que o público concedia uma atenção superficial. Sobre essa planície é que os novos, com estardalhaço, lançam as suas futuras arremetidas, destruindo tudo na passagem e não perdoando pecado algum. A tarefa principal do movimento consistiria, sem dúvida, em destruir o existente, o dominante, o consagrado, de vez que não era consagrado senão pelo apreço de pares e dele apenas vivia.

Not exceptionally, even in a study that proposes examining the "economic basis" of Brazilian literature, the findings do not surpass formal categories, ideology and intellectual morality. The economic components, as well as the analysis of other related historical data, remain in the background. The simple mention of material conditions and other historical components does not affect the overall appraisal of the literary period because there is no serious effort to integrate statistical data into the analysis of the literary production. In other words, Sodré does not fully incorporate economic elements as conditions for the possibility of movements such as Modernism. The author briefly mentions the development of the press and of the book industry in Brazil, but he does not analyze in depth the correlation between these infrastructural transformations and the emergence of an avant-garde literary production in the $1920 \mathrm{~s}^{10}$

\footnotetext{
10 Sodré's data are also imprecise because they refer to a much larger period of time than that of Modernism. Sodré does not specify when the "development of the press" takes place and how it could be interpreted as a determinant of the changes in the literary field. The reference is too vague and could pertain to a great deal of the literary production in Brazil prior to the 1920s. Also, the "emergence of the book industry" can be traced back to the late nineteenth century. For an excellent study about the publishing industry in Brazil, see Hallewell.
} 


\section{Literary Historiography in Brazil}

The passages cited from Coutinho, Lima and Sodré's work allow us to observe that literary historiography's appraisal of the Modernist movement coincides wholeheartedly with what the Modernist intellectuals claimed about their own position in the cultural field. All of the Modernist manifestoes and a considerable amount of their literary production thematically attack Parnassianism and proclaim a new role for the artist/intellectual in society. Yet, whether the Modernists in fact carried out their goals remains a matter of debate. In light of the impossibility of discursive neutrality or total impartiality, what is expected from the work of literary criticism and historiography is a certain distance from its object of study. In other words, the problem with the discourses of literary historiography on Modernism lies not in the fact that they took the side of the Modernists but in the fact that mediation is virtually abandoned in favor of reproduction. Literary historians take the core of Modernist manifestoes at face value, replicating it as dogma, without making an effort to analyze the issues at stake in the political and cultural fields at the time.

This apparent analytical simplification cannot be attributed solely to methodological or theoretical limitations. Any method carries a set of underlying assumptions that satisfy an ideological purpose. By neglecting a great deal of extraliterary information about Modernism, the idealized, official version of the movement has blurred the issues at stake in the struggle for hegemony in the cultural field. Literary historiography has overlooked the agents behind the movement and the political implications of the reconfiguration of the intellectual field at the time. The information about some of the sponsors of the movement is euphemistically presented as background. For example, the sponsorship of the 1922 Week of Modern Art - the event that symbolically inaugurates Modernism - is attributed to the São Paulo coffee aristocracy personalized by Paulo Prado, Olívia Guedes Penteado and others. However, apart from their names and the fact that they are members of São Paulo's aristocracy, no further detail is given: 


\section{Saulo Gouveia}

Em fevereiro de 1922 realiza-se a célebre Semana. Tem pronto apoio moral, muito significativo, de duas figuras expressivas da aristocracia paulista: D. Olívia Guedes Penteado e Paulo Prado. Tem a colaboração direta de Graça Aranha, que com o prestígio de uma obra literária de valor, de membro da Academia Brasileira de Letras e de sua cultura européia, vem do Rio emprestar aos moços um apoio também muito significativo. (Amora 184)

A careful analysis of these contributions by São Paulo's aristocracy would inevitably expose many contradictions in the generally accepted concept of Modernism as a challenge to bourgeois art. In order to interpret the involvement of São Paulo's coffee aristocracy in the event, it would be necessary, first of all, to explain exactly what kind of "moral" support they provided. Furthermore, one would have to address questions of what interests this particular group would have in supporting an avant-garde movement that (at least outwardly) viciously attacks the values of the upper classes. By the same token, a careful analysis of the significance of the involvement of Graça Aranha, a prestigious member of the Academia Brasileira de Letras, would have revealed another contradiction in regards to the supposed Modernist challenge to the literary establishment. That is, if the collaboration of a member of the Academia was something desirable for the Modernists at the time, then one possible meaning of Graça Aranha's involvement with the movement would be that the younger generation ultimately aspired to that same institutionalized and prestigious position within the cultural field. This argument is in fact corroborated by Oswald de Andrade's first attempt to become a member of the Academia in 1925, still in the so-called "heroic" phase of Modernism. He launched his candidacy to the ABL again in 1940 (Rabello iii-iv). On the other hand, Graça Aranha himself breaks with the Academia around that same time (Coutinho \& Sousa 253).

The historiography on Modernism tends to disregard the fact that most Modernists had been attempting to establish themselves as writers under the same institutionalized literary circle they begin to attack in 1922 . There are no explanations for their sudden conversion to avant-garde aesthetics other than dissatisfaction with the cultural environment in which 


\section{Literary Historiography in Brazil}

most of them were already relatively well-established. Furthermore, none of the historiographic accounts examined here establish causal connections between the collective intellectual "rebirth" under the rubric of Modernism and the support conferred upon Modernist intellectuals by members of the elite.

Patronage is described as "moral support," as "disinterested" acts of dilettantism from open-minded aristocrats. If the link between aesthetics and politics were to be clearly elucidated, the connection between Modernist production and conservative political forces would surface. These issues are excluded from traditional literary historiography not just because they constitute extra-literary material, but because they challenge the set of values (the underlying assumptions) upon which the entire set of hegemonic discourses, including literary historiography, is built.

It would be anachronistic to judge this body of literary historiography according to theoretical and analytical standards established much later in academia. For example, literary historiography of the 1950 s should not be expected to include analysis of the market for avant-garde poetry in the 1920 s, or an extensive examination of the broader political and economic circumstances, if that component was not, and still is not, part of the field's praxis. However, as I demonstrated above, theoretical and methodological innovations in literary studies, though not completely ignored, have hardly affected the general ideology presented in these publications. Against literary historians' claims that "extra-literary" issues have only peripheral relevance for their conceptualization of literary phenomenon, I have demonstrated that the argument for "rupture," "renovation" and "engagement" as features of the Modernist movement refers to political and ideological issues, not merely aesthetic ones.

Randal Johnson has stated that the discourse of literary criticism during the 1930 s and 40s oversimplifies the relationship between literature and society in Brazil. This discourse reduces literature to a representation of reality and makes: "even more indefensible assertions that the "subversion" of syntax is somehow tantamount to the political 
subversion of the power structures of Brazilian society" ("The Dynamics" 6). I would add to Johnson's comments that this type of discourse is not only indefensible but also encrypted, obscure and misleading. By establishing a direct analogy between aesthetic experimentation and political subversion, literary historiography affirms its own ideological position in the cultural field and, at the same time, disguises the specific political content of the Modernist production under the aesthetic.

\section{Conclusion}

Returning to the questions I proposed to address, I can affirm with a great degree of certainty that the theoretical framework that influences most of the 1950s studies is, generally speaking, formalist. New Criticism, Russian Formalism, and Benedetto Croce's Neo-Hegelian Idealism (or an eclectic combination of the former) predominate. Marxist theory is also present, albeit superficially, in the work of Nelson Sodré. Antonio Candido's mode of historiography is the only one that articulates a truly historical analysis of the literary phenomenon.

As far as the position that literary historiography occupies in the cultural field and the institutions that legitimize this area of scholarship, I observed that the authors of literary histories are usually high-ranking members of institutions of higher education. Some were also members of government agencies linked to the state cultural and educational apparatuses (e.g., Alceu Amoroso Lima and Álvaro Lins). Therefore, literary historiography was practiced by those with a high degree of authority. It is still an area that occupies a dominant position in the cultural field. The main ideologues and the leading scholars in the area of literary historiography in the 1950s were Alceu Amoroso Lima, Álvaro Lins, Afrânio Coutinho and Antonio Candido. Several others can be cited as important and influential scholars in this area, but they are usually influenced or mentored by one of these four scholars.

Perhaps the most important conclusion I was able to draw from the analysis of the actual content of the texts selected 


\section{Literary Historiography in Brazil}

for this study is that, regardless of the theoretical and methodological framework applied in these studies, their view of Brazilian literature, and the literary phenomenon in general tended to converge. I took as an example, their assessment of the Modernist movement in Brazil, and I was able to determine that the predominant discourse of literary historiography operated strictly within the institutional habitus, reproducing by and large the hegemonic view of the subject.

Literary historiography in Brazil still remains not only predominantly formalist but also a corporate field. As a result, the content of these "histories" of Brazilian literature tend to perpetuate a limited and homogenizing view of the literary phenomenon. This body of scholarship has elided a great deal of history as well as the politics involved in the process of legitimization of Modernism. The 1950s body of literary historiography not only canonized Modernism as the summit of Brazilian intellectual history but it gained legitimacy by reaffirming the greatness of the Modernist legacy. This is a classic case in which the imposition of a formalistic view of the literary phenomenon, in spite of its claim of neutrality, impartiality and of the autonomy of the literary text, served the political and ideological agenda of those who were invested in the canonization of Modernism. The field of historiography established a monopoly over the legitimate definition of literature imposing a centralized view of Brazilian literature. Despite its shortcomings, this discourse continues to be disseminated in the educational system.

\section{Works Cited:}

Amora, Antônio Soares. História da literatura brasileira (Séculos XVI-XX). 2nd ed. São Paulo: Saraiva, 1958.

Bosi, Alfredo. "Por um historicismo renovado: Reflexo e reflexão em história literária." Literatura e resistência. São Paulo: Companhia das Letras, 2002. 7-53.

---. História concisa da literatura brasileira. 33rd ed. São Paulo: Cultrix, 1994.

---. O pre-modernismo. São Paulo: Cultrix, 1973. 
Bourdieu, Pierre. The Field of Cultural Production: Essays on Art and Literature. Trans. Richard Nice. Ed. Randal Johnson. New York: Columbia UP, 1993.

--- "The Field of Cultural Production, or: The Economic World Reversed." Bourdieu 29-73.

---. "The Production of Belief." Bourdieu 74-111.

---. The Logic of Practice. Trans. Richard Nice.

Cambridge: Polity, 1990.

Candido, Antonio. Formação da literatura brasileira:

Momentos decisivos. 2 vols. São Paulo: Martins, 1959.

--- \& José Aderaldo Castello. Presença da literatura brasileira: Modernismo. 6 ed. Rio de Janeiro/São Paulo: DIFEL, 1977.

Castello, José Aderaldo. A literatura brasileira: Origens e unidade. 2 vols. São Paulo: Edusp, 1999.

Coutinho, Afrânio. Introdução à literatura no Brasil. 8th ed. Rio de Janeiro: Civilização Brasileira, 1976 [1959].

--- ed. A literatura no Brasil: Modernismo. Vol. 5. Rio de Janeiro: Sul Americana, 1970 [1955].

--- \& José Galante de Sousa, eds. Enciclopédia de

literatura brasileira. 2 vols. 2 ed. Graça Coutinho \& Rita Coutinho. Rio de Janeiro: FBN/ABL, 2001.

Guillory, John. Cultural Capital: The Problem of Literary Canon Formation. Chicago\&London: U of Chicago P., 1993.

Hallewell, Laurence. Books in Brazil: A History of the Publishing Trade. Mituchen \& London: Scarecrow, 1982.

Johnson, Randal. "The Institutionalization of Brazilian Modernism." Brasil/Brazil III.4 (1990): 5-23.

---. "As relações sociais da produção literária." Revista de Crítica Literária Latinoamericana. 20.40 (1994): 189-203.

---. "The Dynamics of the Brazilian Literary Field, 19301945." Luso-Brazilian Review 31.2 (1994): 5-22.

---. "Editor's Introduction: Pierre Bourdieu on Art, Literature and Culture." Introduction. Field of Cultural Production: Essays on Art and Literature. By Pierre Bourdieu. Trans. Richard Nice. Ed. Randal Johnson. New York: Columbia UP, 1993. 29-73. 


\section{Literary Historiography in Brazil}

Lima, Alceu Amoroso. Contribuição à história do modernismo: O premodernismo. Rio de Janeiro: José Olympio, 1939.

---. Quadro sintético da literatura brasileira. 2 ed. Rio de Janeiro: AGIR, 1959.

---. Introdução à literatura brasileira. Rio de Janeiro, AGIR, 1956.

Lins, Álvaro. Ed. História da literatura brasileira. 12 vols. Rio de Janeiro: J. Olympio, 1950.

Malard, Letícia, "Nelson Werneck Sodré: A ruptura e o reflexo." História da literatura: Ensaios. Letícia Malard et.al. Campinas: UNICAMP, 1994: 55-74.

Martins, Wilson. "A crítica modernista." A literatura no Brasil. Vol. 5. Ed. Afrânio Coutinho. Rio de Janeiro: Sul Americana, 1970. 493-535.

Miceli, Sérgio. Intelectuais e classe dirigente 1920-1945. São Paulo: DIFEL, 1979.

Milliet, Sérgio. Panorama da moderna poesia brasileira. Rio de Janeiro: Ministério da Educação e Saúde, Serviço de Documentação, 1952.

"Nelson Werneck Sodré." Centro de Pesquisa e Documentação de História Contemporânea do Brasil. 2005. Fundação Getúlio Vargas. 23 April 2009.

$<$ http://www. cpdoc.fgv.br/nav_gv/htm/biografias/

Nelson_Werneck_Sodre.asp $>$.

Ortiz, Renato. Cultura brasileira e identidade nacional. São Paulo: Brasiliense, 1985.

Pereira, Lúcia Miguel. Prosa de ficção (De 1870 a 1920). 2nd ed. Álvaro Lins, Ed. História da literatura brasileira. Vol. 12. Rio de Janeiro: José Olympio, 1957.

Rabello, Maria Alice. "Cronologia." Oswald de Andrade. Pau-brasil. 5 ed. Obras completas de Oswald de Andrade. São Paulo: Globo, 1991. i-v.

Romero, Sílvio. História da literatura brasileira. 1888. 3rd ed. Rio de Janeiro: José Olympio, 1943.

Sodré, Nelson Werneck. História da literatura brasileira: Seus fundamentos econômicos. 4th ed. Rio de Janeiro: Civilização Brasileira, 1964. 


\section{Saulo Gouveia}

Ventura, Roberto. "História e crítica em Sílvio Romero," Letícia Malard et al. História da literatura: Ensaios. São Paulo: Unicamp, 1994. 34-54.

Veríssimo, José. História da literatura brasileira. De Bento Teixeira (1601) a Machado de Assis (1908). 4th ed. Brasília: Universidade de Brasília, 1963 [1916].

Williams, Daryle. Culture Wars in Brazil: The First Vargas Regime, 1930-1945. Durham \& London: Duke UP, 2001. 